University of Louisville

ThinkIR: The University of Louisville's Institutional Repository

8-1948

\title{
A sociological study of part time employment in the senior high schools of Louisville, Kentucky.
}

Thomas Hoskins Kettig

University of Louisville

Follow this and additional works at: https://ir.library.louisville.edu/etd

Part of the Sociology Commons

\section{Recommended Citation}

Kettig, Thomas Hoskins, "A sociological study of part time employment in the senior high schools of Louisville, Kentucky." (1948). Electronic Theses and Dissertations. Paper 1980.

https://doi.org/10.18297/etd/1980

This Master's Thesis is brought to you for free and open access by ThinkIR: The University of Louisville's Institutional Repository. It has been accepted for inclusion in Electronic Theses and Dissertations by an authorized administrator of ThinkIR: The University of Louisville's Institutional Repository. This title appears here courtesy of the author, who has retained all other copyrights. For more information, please contact thinkir@louisville.edu. 
UNIVERSITY OF LOUISVILLE

A SOCIOLOGICAL STUDY OF PART TIME GMFIOYMENT IN THE SENIOR HIGH SCHOOLS OF LOUISVILLE, KENIUCKY

\author{
A Dissertation \\ Submitied to the Froulty \\ in Partial Fulfillment of the \\ Requirements for the Degree \\ of Master of Arts
}

of the Graduate Sohool of the University of Louisville

Department of sociology

by

Thomas Hoskins Kettig

Year

1948 


\section{UNIVERSITY}

LIBRARIES

This PDF document is a scanned copy of a paper manuscript housed in the University of Louisville (UofL) Libraries. The quality of this reproduction is greatly dependent upon the condition of the original paper copy. Indistinct print and poor quality illustrations are a direct reflection of the quality of materials that are available for scanning. The UofL Libraries greatly appreciates any better copies that can be made available for replacement scans. 


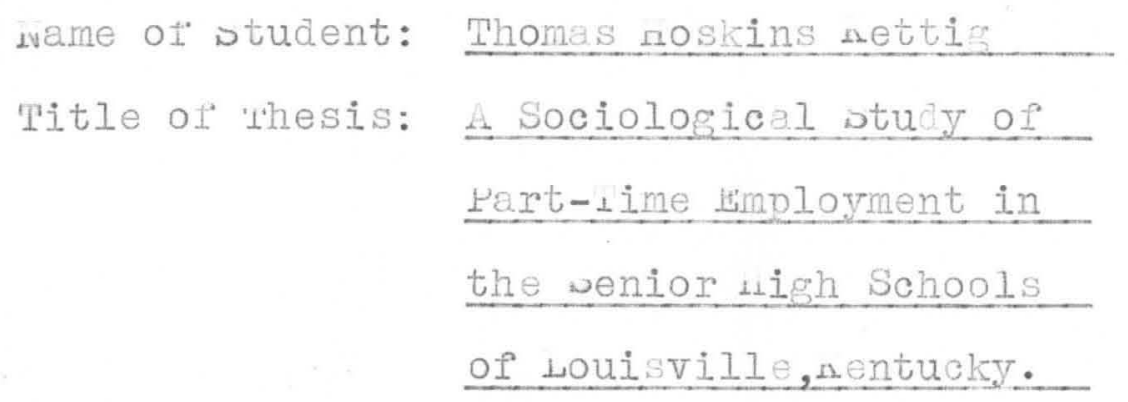

vame of virector: Dr. Robert nutak

Approved by a readin vomittee composed of the following mernbers:

Ernest C. Hassold

R. L. Birdwhistell

Robert I.Kutak

Date: Aceg. 13,1948 
Aiv ACKNOWLEDGEMEINI

In witing this thesis, it was neoessary to have the cooperation of many people, both the students who volunteered the information, and the members of the faculties. This is by way of thanking them. Espeoial thanks is due to Dr. Robert Kutak, who directed work. Likewise I wish to thank Dr. Ernest Hassold, Mr. Ray Birdwhiste1l, and Dean Hilda Throlkeld who served on my reading comittee. Too, I wish to thank all of the memuers of the board of education, as well as the individual students, teachers, and principals who made possible the success of this report.

In conclusion I extend my appreciation to my wite, Shirley Kettig, for her invaluable aid in the preparation of this thesis. 
Table of Contents

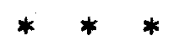

Chapter

Page

I. Introduction . . . . - . . . . . . . . 1

II. The Analysis of the Data - . - . - . - 4

1. Aralysis of Local Data • • • • • . 9

2. Job Classification . . . . . . . 21

3. Other Aspects of the Louisville Analysis . . 29

4. Analyses from Other Cities . . . . 31

III. The Cooperative Work Program . - . . - . 36

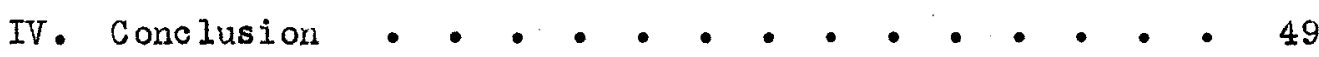

Biuliography: . . . . . . . . . . . . 51

Appendix: • • . . . . . . . . . . . 52

(Schedule of Question for Part l'ime Work in High Sohools) 
CHAPTER ONE

INTRODUCTION 
CHAPTER I

INRRODUCT ION

Planning for the kind of economic progress that will promote the general welfare must include development of human resources. Each generation of the nation's boys and girls as they grow up must be given whatever equipment is necessary to make them citizens with a vision of their responsibilities and capacity for personal developmeiti and social usefulness. Ways of satistying their education and employment needs $\ldots \ldots \ldots$ are of vital importance. (1)

Today with the advent of an ever increasing industrialization, the importance of developing the skill, strength, and knowledge of the young people to meet the now age is recognized as never betore. Wot only must the fundumentalism of traditional education be revisea in terms of a more progressive education, but also the practical, non-academic courses should be given more consideration.

In this thesis I have attempted to analyze one particularly important aspect of the problem of youth and employment. I have presented here a sociological analysis of part-time employment in the Louisville, Kentucky senior High Schools. It was my intention to inquire into the relationships between the time spent in employment and the effects on the students' scholustio and social lives. Throughout the thesis I have endeavored to show the efiects on the community of a school work program.

The main body of the thesis is divided into three chapters: ari introduction, a report of the analysis of the data, and a summary of trends and proposals. Ihe particular questious posed by the investigation, the methodology, and the analysis of local and national data will be presented in chapter two.

At the begiuring, a brief history of the concept of the relation-

(1) Educational and Employment Opportunities of Youth: U.S. Dept. of Lacor: Division of Labor Standards, Child Labor and Youth Employment Branch: Washington, D. C. 
ship of work and education in the United States should be presented.

In the early Colonial days in North America, the work and education both centered around the home. In fact, most of the vital elements of existence were to be found in the home. Iline home work shop was the key to production. Ihus, in learning a trade, a boy or girl merely became an apprentice to his father or mother. In such a way, cabinet making, weaving, cooking, anà carpentry were passed on to each succeeding generation. Ihere tended to develop an interrelated work and education program, since the children were getting an education through their apprenticeship. Lhese apprenticeships were often long and required particular attention on the part of the parents.

With the coming of industrialization of production, however, this handicraft economy broke down, throwing thousands of young people into the routine of factory life. For this segment of the population, litile formal education was possible. Iritially weak child labor laws have been gradually replaced with the child labor laws of today; consequently more formal education has been made possible for those of lower economic status. The basic philosophy of this movement has been to take the child away from. work and put him into the classroom.

$$
\text { From } 1900 \text { to 1940, one saw the emphasis being placed on formal }
$$
education divorced from part-time employment. In addition to legislation forcing more formal education, the lack of industrial opportunities during the depression years kept many young people in school who otherwise would have been on the job market. In 1940, war demands opened an entirely new field of opportunity for many adolescents who were eager to go into industry. During the war, many young people cut short their education 
thus handicapping their future. Nany received higher wages than customary in normal times for the jous they held. For some of these youngsters, wartime social conditions interfered with a home life favorable to a sound development of personelity.

In order to help satisfy these education-employment needs both of the post-war years and the years ahead, some communities have formulated a correlated school-work program. These programs will be discussed in the concluding chapter. Although the necessity for such a program is no less vital in Louisville, little progress has been made in organizing such a system.

It is with a realization of these needs in the local cormunity, that the following thesis is presented. 
CHAPIER TWO

THE ANALYSIS OF DATA 
CHAPTER II

THE ATALYSIS OF DATA.

Nothodology

In order to analyze the problems of the high school students, I used a survey. A copy of the questionnaire employed in the survey is included in the appendix. The questions were intended to stress the inter-relationship of academic, social, and employment problems. The survey was made in the following senior high schools in Louisville, Kontucky:

'Pheodore Ahrens Trade School

J. M. Atherton School for Girls

Central Colored High School

Reuben Post Halleck Senior High School

Louisville Male High School

Du Pont Mauual Training High School

Shawnee Senior High School

Fere I wish to state the soope and limitations of my survey. The data in the analysis were obtained through voluntary answers, there being no compulsion to answer. Since this was so, no control group could be set up to make precise statistical measurements. "Whus the data have been used to show the major trends, not to establish delinite mathematioal formulation of any of the questions posed. In the conclusion I have endeavored to build a program suggested by the trends and data secured through this survey and those reported in other cities.

'I'o of fset the lack of a control group. I did have very good cooperation from the representatives of the working students of the various schools. Ihis cooperation was due largely to the fuct that the students 
know that no school authorities would have access to their answers. This was stressed in a number of cases where the students indicated a wiIingness to answer my questions, provided that no school authorities saw the replies. This I found encouraging because I velieve the questions were answered sincerely and without recourse to "official" answers in order to produce a favorable impression on the instructor.

Similar surveys have been conducted in other cities, sometimes using a control group to check IQ or scholastic recoras. Some of these surveys have been included in the latter part of this chapter to present evidence from elsewhere. In considering these analyses of surveys, the Iimitations and advantages of a comparison must be understood. By having some perspective of other cities' needs and problems, one is better able to visualize local problems. Ihis cuitural pattern which sets so many of the ideals of our adolescents has many variables, but more important are the similarities that may be seen as one compares the aims and ambitions of the nation's youth.

The methodology which was employed in the survey, will now be summarized. I was confronted with the lack of certain material essentials for making a scientific investigation. I had no control group, and I had Iittle data available from the Board of Education. There simply was no department operated by the Board which had ever made such investigations on a compulsary basis. I'hus where I needed the Ii of an individual, for example, it was necessary to rely upon an IQ obtained several years before.

The sampling techique which I employed was based on the following two assumptions: (1) relatively f'ew sophomores would hold a job in comparison to seniors and juniors due to minimum employment age; (2) a study hall or English class would yield as average a group as could ue 
oviained. 'l'he questionnaires vere administered personaily at Male, Manual, Central, and Atherton. It was impossible to do this at Ahrens, Halleck, and Shawee, so I left the questionnaires with the study hall teachers, and secured the completed forms later. Ot the total 228 questionnaires, 105 were secured in the latter fiashion.

After the schedules were completed, I next secured the academic information from the school records. My purpose in reporting average scholastic records was to see if general academic work was interfered with by part-time employment. In reporting IQs, I wanted to ascertain the median IQ of the students interviewed.

The IQ in all cases reported was based on a standard intelligence test which is given to all sixth grade siudents in the Louisville Public school system. Although in certain cases other intelligence tests were used, only the Otis IQ was selected, in order to keep all data comparable. It should be recalled when using the IQ data trat these tests had been given five to seven years previous to the scholastic work compared. During so long a time, various types of social maladjustments or readjustments may arise which would result in low correlations between $I Q$ and the average scholastic record.

The average scholastic record was secured from the individual record cards. In general, what was wanted from these records was an approximate percentage which would epitomize the academic work of the student. In the case of Anrens Trade School, I interpreted its system in terms of percentages. (*) There were several failures in all of the schools, particularly among those students whose overall average was less than 75 per cent. After summarizing these grades, the general major trends are indicated.

* Ahrens Irade School keeps its record in terms of satisfactory and unsatis factory. Satisfactory corresponds roughly to A, B, and C of the traditional system. Thus these Ahrens grades were converted to the regular basis. 
After the survey was completed, the following seemed of the most importance:

(1) A relationship between IQ and Average Scholastic Record.

(2) A classification of IQ acoording to school.

(3) A relationsinip vetween the Average Scholastic Record and hours spent per week in work.

(4) A relationship of the time spent at extra-curricular activities and hours spent per week in employment.

(5) A relationship between the hours spent in employment and the hours spent in outside school assignments.

(6) An analysis of the classification of jobs.

(7) A relationship between the amount of time employed and the financial need for work.

(8) A relationship between the financial need of the parectis, and the need for the student's employment.

These relationships will constitute tine main body of my inquiry and analysis. I shall take each protlem and present my data pertinent to it. The analysis of the national surveys will then be givon. Before startiag the analysis, I shail present the following table showing the distribution of returns according to sohools. Ihis is done since some schools were not as well represented as others, thus making impossible a strict sampling on the basis of population.

\section{TABLE I}

A CLASSIFICALIOH OF LHE DISIKIBUH IOH OF RETUKNED QUESP TOMHAIRES FROM A

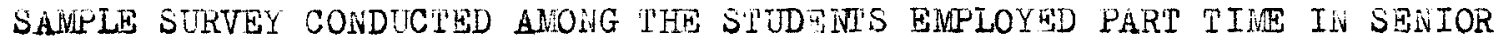
HIGH SCHOOLS OF LOUISVILLE, KGTPUCKY, APRIL, 1947.

\begin{tabular}{|c|c|c|}
\hline \multicolumn{2}{|c|}{ Schools: } & I'otal Forms Returned \\
\hline Ainrens, & Boys & 21 \\
\hline & Girls & 16 \\
\hline Atherton, & Girls & 18 \\
\hline Central, & Boys & 15 \\
\hline & Girls & 11 \\
\hline Halleck, & Girls & 36 \\
\hline Male, & Boys & 24 \\
\hline Nianual, & Boys & 36 \\
\hline Shawnee, & Girls & 51 \\
\hline
\end{tabular}

Total: Boys 96

Total: Girls $\overline{132}$ 
Although a total of 228 questionnaires were returned, all of them were not comple tely answered. For example, some of the students answered only five or eight out of the total 228 questions. Again in some cases, I was unable to secure an Ia because the student had come from a system in which no IQ was reported. The net result is that all questions on the schedule will not be represented by 228 replies. Sinoe in some tables only five or six cases were tabulated that fitted the particular circumstances, percentages have been used rarely. 'the only instances which warranted percentages were statements involving more than one hundred cases. 
Analys is of Local Data

In this section I shall present my findings relevant to the local analysis. The several relationships mentioned in the last section will be treated separately. Ihe first relationsinip to investigated is that of $I Q$ and the average scholastic record. By referring to lables III and IV, it is seen that there is not a close relationship between these two variables. 'This low relationship is not too startling if one considers that a period of from five to seven years has elapsed since the IQ test was administered. A more recent IQ test during the high school yeur would be desirable.

By referring to Table III, the following median IQ's were obtained for the schools as indicated.

\section{TABLE II}

A CLASSIFICATION OF MEDIAN IQ BASED ON A SAMPLE SURVEY CONDUCTED AMONG THE STUDENTS EMPLOYED PART TIME IN SENIOR FIGH SCHOOLS OF LOUISVILLE, KENTUCKY, APRIL, 1947.

\section{School}

Ahrens,

Boys

Gir ls

Atherton, Girls

Central, Boys

Girls

Halleck, Girls

Mile, Boys

Hanual, Boys

Shawnee, Girls
Median IQ

108

103

103

98

98

98

111

108

100

Median for all schools reporting: 103 
A CLANDTFICALION OF IQ'S BASED ON A SAMLLE SURVEY CONDUCLED AMONG IHE SIJD WNIS EMLLOYED PART I'IME IN SELIOR HIGH SCHOOLS OF LOUISVILLE, KEHIUCKY, APRIL, 1947 .

IQ Range

Schools Purtioipating

$\frac{\text { AHRENS }}{\text { Boys Girls }} \frac{\text { ALHERIO }}{\text { Girls }} \frac{\text { CENIRAL }}{\text { DOys Girls }} \frac{\text { HALLECK }}{\text { Girls }} \frac{\text { MALE }}{\text { BOys }} \frac{\text { MANUAL }}{\text { Boys }} \frac{\text { SHAMNES }}{\text { Girls }}$ POTAL

\begin{tabular}{|c|c|c|c|c|c|c|c|c|c|c|}
\hline $81-5$ & 2 & $I$ & 1 & 2 & 3 & 3 & & 2 & 1 & 15 \\
\hline $96-90$ & & 1 & & & 2 & 4 & & & 3 & 10 \\
\hline $91-5$ & & 2 & 4 & & & 3 & & 4 & 8 & 21 \\
\hline $96-100$ & 3 & 4 & & 3 & & 7 & 1 & 6 & 12 & 36 \\
\hline $101-5$ & 2 & 1 & 2 & 2 & 1 & 3 & 2 & 5 & 9 & 27 \\
\hline $106-110$ & 5 & 3 & 4 & 5 & & 5 & 5 & 8 & 6 & 41 \\
\hline $111-15$ & 2 & $I$ & 2 & 2 & & 3 & 4 & 8 & 6 & 28 \\
\hline $116-20$ & & 4 & & & 2 & & 2 & 4 & 4 & 16 \\
\hline $121-5$ & 1 & I & 2 & 1 & 1 & 2 & 4 & & 1 & 13 \\
\hline $126-U p$ & 1 & & 1 & 1 & & & 1 & 3 & & 7 \\
\hline T̃otal & 16 & 18 & 16 & 16 & 9 & 30 & 19 & 40 & 50 & 214 \\
\hline
\end{tabular}

This IQ distribution is about normal, and although some schools fall below or some higher than the median of 100, this could be expected in such a sampling as I had obtained. Thus the trend of IQ as far as this population is concerned, appears reasonably normal, with the boys of this group having a slightly higher median than the girls.

If one were to account for the difference in the median IQ's for the various schools, it would require a greater numoer of cases to reach ary definite conclusions. However one pertinent fact may be cited. The lower IQ's at Central are explained by the poorer past educational opportunities of the Vegroes. Whe variance in the IQ among the other schools should not be considered significant. 
There is no substantial evidence to indicate that the In of the working population deviates appreciably from the group of students who are not employed. That is, one would expect to find, according to this survey, as large a percentage of superior persons among this group of people working part time, as one would find in any large group. It would seem desiraule to have known the median If of the entire high school student body for each school to use as a control group, but the schools could not supply such information.

Below is presented a table which shows the classirication of the scholastic averages for the high schools visited.

\section{TABLE IV.}

A CLASSIFICAPION OF THE AVERAGE SCHOLASTIC RECORDS BASED ON A SAMIPLE SURVEY CONDUCTED AMIONG THE STUDENTS EMPLOYED PART TIME OF THE SENIOR HIGH SCHOULS' OF LOUISVILLE, KENTUCKY, AFRII, 1947.

SCHOOLS

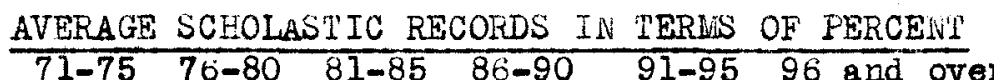

TOTAL

Ahrens, Boys (Grades not given in percentage; seo page 7 for explanation.) Girls

\begin{tabular}{lccccccc} 
Athertion & 5 & 4 & 4 & 5 & 3 & 1 & 22 \\
Central, & Boys & 2 & 2 & 3 & 3 & 2 & \\
& Girls & & 4 & 4 & 3 & & 12 \\
Halleck & 12 & 6 & 7 & 6 & 1 & 1 & 11 \\
Mialo & 7 & 5 & 3 & 4 & 3 & 1 & 27 \\
Manual & 21 & 8 & 6 & 3 & & 1 & 23 \\
Shawnee & 17 & 17 & 14 & 7 & & & 39 \\
\hline Total & 64 & 40 & 41 & 31 & 9 & 4 & 189
\end{tabular}




\section{TABLE V}

A DISTRIBUTION OF THE MEDIAIV SCHOLASTIC RECORDS BASED ON A SAMPIE SURVEY CONDUCIED AMONG THE STUDONTS EMPLOYED PARI TIME IN THE SEIIOR HIGH SCHOOLS OF LOUISVILLE, KENTUCKY, APRIL, 1947.

SCHOOLS

Atherton

Central

Hallook

Ma le

Manua 1

Shawnee

Median for all of the schools:

\section{MEDIAN SCHOLASTIC PERCENTAGE}

86

83

81

80

74

78

With regard to grades, it should be remembered that no positive comparison can ever be made between the several schools, since the standards, techniques, and the teaching devices are so different. However, over and above this aspect of the comparison. I think the most striking fact of this compilation is the relatively low median record of all the schools grouped together, i.e., a median of 80 . When one t'inds such a large percentage of the working group fialing in this category, two questions are immedisiely asked: (1) Are these unusually large numbers of low grades caused by the fact that the students work, or (2) Do the students who would be doing poor work (academic) under any conditions, take the jobs?

It seems that possibly the source of the large group of low marks in the cases studied lies more in the realm of social and personality adjustment than in the field of scholastic training. It should be remembered that this large group doing poor work in the schools is not mentally inferior or handicapped, as the IQ distribution is not indicative of men- 
tal incapacity. In the latter portion of the thesis, considerable emphasis is placed on the need for a more suitable joo training program that will take into acoount problems of personality adjustment. The next relationship to be investigated is that of length of hours employed and the scholastic records. For this purpose, overall averages of less than 80 per cent were considered unsatisfactory work. The table following is designed to relate the hours spent in gaintul employment with the number of students having grades averaging less than 80 per cont.

TABLE VI.

A CLASSIFICATIOIN OF THE GRADES AVERAGI IVG IESS THAN 80 PER CEIT, GROUPED ACCORDING TO THE NUMBER OF HOURS SPEVI IN GAINFUL EITLOYMENT, BASED ON A SAMPLE SURVEY COINDUCTED AMOING THE STUDENTS EMPLOYED PART TIME IN SEUIOR HICH SCHOOLS OF LOUISVILLE, KENIUCKY, APRIL, 1947.

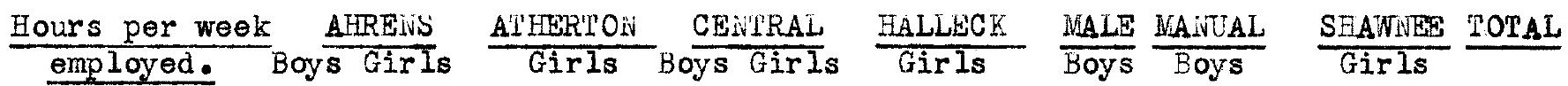

\begin{tabular}{|c|c|c|c|c|c|c|c|c|c|}
\hline $1-9$ & & $I$ & 4 & & $\ddot{z}$ & 11 & 2 & 2 & 17 \\
\hline $10-19$ & 3 & 5 & 2 & 1 & & 2 & 4 & 9 & 9 \\
\hline $20-29$ & 2 & 3 & & 3 & & 2 & 1 & 14 & 2 \\
\hline 30 and over & 3 & & & 2 & & & 3 & 6 & \\
\hline TotaI & 8 & 9 & 6 & 6 & 2 & 15 & 10 & 31 & 28 \\
\hline
\end{tabular}

It is seen from Table VI that little relationship exists between the hours employed and poor grades, since there were as many poor grades among the students working only a few hours as there were among the students working long hours. In order to ascertain what percentage of cases were doing unsatisfactory work, the following table was made. It is seen that 115 out of 228 students reporting are doing unsatisfactory academic work. 


\section{TABLE VII}

A CLADSIFICATION OF STUDENTS WHO HAVE LESS THAN 80 YGR CEIVI AVERAGE FOR SCHOLASTIC RECORDS, BASED ON A SAYFLY SURVEY CONDUCTED ANONG THE SENIOR HIGH SCHOOIS SIUDENTS ERPLOYED PART TIME IN LOUISVILLE, KENTUCKY, APRIL, 1947 .

School

Students Who Had Less ihan 80 Per Cent

AHREIVS,

$$
\text { Boys }
$$

8

21

$$
\text { Girls }
$$

16

ATHERTON, Girds

6

18

CENIRAL,

Boys

6

15

Girls

11

HALLECK, Girls

15

30

MaLE',

Boys

10

24

manuát,

Boys

31

30

SHAWNEE,

Girls

28

51

Total

115

228

Table VII shows that a very high percentage of all the students included in the part-time work group are doing poor scholastic work. Although they may be passing their subjects, the median for their work is under the grade established as average, that is 85 . In order to better compare the information of Table VII with the total numbers of hours of employment, Table VIII follows. 
A CLASSIFICAIIIN OF THE NTMBER OF HOURS WORKED PER WEEK BY TEE SCHOOLS REPORTING IN A SAMPLE SURVEY CONDECTED AMONG THE S'IUDENTS EMPLOYED PAR' TIDE IN THE SENIOR HIGH SCHOOLS OF LOUISVILLE, KEITUCKY, APRIL, 1947.

School

$$
\frac{\text { Hours Employed Per Nieek }}{1-9 \quad 10-19} \frac{20-9 \quad 30 \text { and ov er }}{10}
$$

Total

\begin{tabular}{llccccc} 
AFREIS, & Boys & 1 & 5 & 9 & 6 & 21 \\
& Girls & 2 & 7 & 5 & 2 & 16 \\
AIHERTON, & Girls & 8 & 8 & 2 & & 18 \\
CENTRAL, & Boys & 2 & 3 & 6 & 4 & 15 \\
& Girls & 7 & 2 & & 2 & 11 \\
HALIECK, & Girls & 21 & 10 & 5 & & 36 \\
MALE, & Boys & 9 & 7 & 5 & 3 & 24 \\
MANUAL, & Boys & 5 & 10 & 15 & 6 & 36 \\
SHAWNEE, & Girls & 29 & 16 & 4 & 2 & 51 \\
\hline Total & & 84 & 68 & 51 & 25 & 228
\end{tabular}

The jobs requiring long hours of employment are largely positions for boys, since 21 of the 25 people working over 30 hours per week were poys. From Table VI, it is also seen that 14 out of the 28 students working over 30 hours per week are doing poor academic work. In order to illustrate the effects of long hours of employment, a few direct statements from random questionnaires are pertinent:

As a rule I would like to stop working such long hours after sohool, as it interferes with my studying, but I live only with my brother and mother. The only means of support are from my brother and me.

Working long hours makes me have to do homework late at night, and causes me to be not alert at school.

These comments epitomize the difficulties experienced by many students who are working over ten hours a week. Some difference eas evidenced between boys' and girls' capacities for long hours of work. There 
were more boys working long hours, but the girls who did work long hours maintained a higher scholastic record.

A fow statements from the questionnaire again may make more explioit the problem of interference in the school program.

You are sleepy and can't study as much as you wish. Work hasn't, interfered with. my sohooling but it has with my social lifte.

It may be seen by looking at the above sample replies that such answers indicate a need for better coordination between school and industry, so that the number of students working over thirty hours per week may be reduced.

The median of the work week of the entire sample population is fifteer hours, while the median for the Negroes is approximately sixteon hours. This medien is based on a small rumber of ivegro cases, only 27 reporting. This analysis is included here to indicate that the ivegroes of this community who replied to the questionnaire share to a large extent the same problems as the white population.

Thus there seems to be a tendency, as indicated by this survey, for students to become negligent in their school work and to have little time for recreational pursuits. Part time work under the most ideal situation is not intended to maintain these children in school. It is to provide an opportunity to gain admittance to the adult world of business and industry through a well integrated program. In the last section of the thesis there will be developed the type of work program advocated by educators. 
Now that the background of the problem of long working hours among a relatively large number of students has been given, the next question that may be asked is, "Why do these people work such long hours?" In order to establish a viewpoint fior this question, the following classification was made:

PABLE IX.

A CLASSIFICATION OF STUD INTS WHO CLAIMED IHAI THEIR PART TIME WORK WAS NECESSARY FOR MAINTTNANCE IN SCHOOL AS INDLCALED BY A SAMPLE SURVEY CONDUCTED AWONG THE SENIOR HIGH SCHCOLS OF LOUISVILLE, KENTUCKY, APRIL, 1947.

Hours per week AHRENS ATHERIONi CENTRAL HALLECK MALE MAIYUAL SHAWNEE TOTAL employed. Boys Girls Boys Giris

\begin{tabular}{llllllllll}
$1-20$ & 1 & 1 & 1 & 2 & & 1 & 1 & 3 & 10 \\
over 20 & 4 & 5 & 7 & & 1 & 4 & 4 & 4 & 29 \\
\hline Total & 5 & 6 & 8 & 2 & 1 & 5 & 5 & 7 & 39
\end{tabular}

TOTAL CLAIMING MONEY WAS NECESSARY: 39

Of the students working over twenty hours per week, less than forty per cent reported that the morey was essential; of those working under twenty hours per week, less than ten per cent reported it essential.: This question of long hours of employment seems in many cases to resolve itself into the problem of ootaining enough money for personal purposes. The teen-age money problems are paramount to these young people. Phoebe Gordon has analyzed this conflict and has made certain recommendations. She found that among the students she interviewed, less than 50 per oent reported any interest in working vesides the need for recreation money. In further investigations she learned that olothing and dating money were the two biggest needs among the young people, and that even 
among the boys, clothes were tar Irom unimportant. l'nus in order to reduce the need for such lorg hours of work, she recomended that tre students, in conjunction with their parents, set up a budgeting system so that a smaller amount of morey could se used more wisely for clothing and recreation. (1)

She f'ound recreationa $I$ and extra-curricular activities eliminated from the program of the people who worked, since invariably social functions were planned when it was impossible for working students to attend. 'lhus in order to share equally the privileges and joys of high sohool, it was urged that a planned program be instituted.

In order to see how much time the local students spent in extra-curricular aotivities, the following two tables are presented. Table $X$ shows the amount of time spent by the students working less than 20 hours per week, while Table XI shows the relations existing in the group working over 20 hours per week.

\section{TABLE X.}

A CLASSIFICATION OF HOURS SPEIVT IIV EXIRA-CURRICULAR ACPTVIIIES OF STLDENTS WORKING LESS IEAN 20 HOURS FER WEEK, AS INDICAIED BY A SAMPLE SURVEY OF STUDENTS EMPLOYED PART TIME IN T'HE SBIHIOR HICH SCHOOLS OF IOUISVILLE, KE INIUCKY, APRIL, 1947.

Hours Spent AHREISS ATHERTON CENTRAL HALIECK MALE HANUALI SHAWIVE TOTAL in extra- Boys Girls Boys Girls ourricular

\begin{tabular}{lrrrrrrrrr}
$1-5$ & 1 & 5 & 2 & 2 & 4 & 2 & 5 & 21 \\
$6-10$ & 3 & 6 & 8 & 22 & 2 & 1 & 4 & 16 & 42 \\
$11-15$ & 1 & 2 & 1 & 1 & & 2 & 4 & 2 & 13 \\
\hline Total & 5 & 13 & 11 & 5 & 6 & 5 & 8 & 23 & 76
\end{tabular}

TABLE XI.

A CLASSIFICATION AS ABOVE OF SIUDEIVIS WORKING OVER 20 HOURS A WEEK.

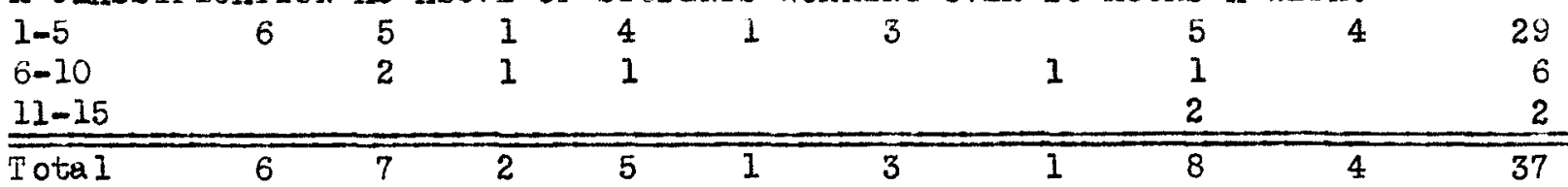

TOTAL SIUDENTS REFORIING EXTRA-CURRICULAR ACTIVIIIES WAS: 113

(1) Gordon, Phoebe: "Teen Age Money Problems". Clearing Fouse: 11: 402-6, March, 1937 
From this analysis it is seen that far more students were able to participate in extra-curricular activities among those working less than twenty hours per woek, than in the group working more than twerty hours per week. Of the total students reporting extra-curricular activities, the average time spent in such enterprises was seven hours per week. However, of the people working over twenty hours per week, 29 out of 37 reporting devoted less than four hours $r$ week to their extra-curricular activities.

Extra-curricular activities for this survey were defined as any sooializing influences, e. g•, athletics, young people's organizations, dobating, dramatios, or churoh group work. The community oooperation that such activities as these could develop is of great value. However, when a part of the young poople of any community are working such long hours that they cannot participate in suoh activities, then there is a serious challenge to the adults to remedy the situation. If, as was indicated, 70 per cent of the students working over 20 hours per week are denied such wholesome recreation, our educational conoepts should be challenged.

Another aspect of the oonflict between working and schooling is the question of homework. As shown in the few sample oomments quoted in this chapter, long hours of work are not conduoive to studying outside of school. Thus in order to get an average value for the amount of time spent out of school on assignments, the following classification was made:

TABLE XI

A CLASSIFICATION BY SCHOOL' SHOWING PHE HOURS SPENT ON HOMEWORK ASSIGNMENTS, AS INDICATED BY A SAMIELE SURVEY CONDUCTED ANOMG THE STUDEINS WORKING FART TINE IN THE SENIOR HIGH SCHOOLS OF LOUISVILLE, KENTUCKY, APRIL, 1947.

Hours per week
Used in homework Boys Girls \begin{tabular}{lllllllllll} 
Used in homework & Boys Girls & \multicolumn{7}{c}{ Boys Girls } \\
$1-5$ & 13 & 16 & 4 & 7 & 6 & 12 & 7 & 23 & 7 & 85
\end{tabular}

$6-10$

Over 10

$\begin{array}{llll}4 & 2 & 12 & 2\end{array}$

Total

\begin{tabular}{lrrrr}
1 & 2 & 3 & 2 & 1 \\
\hline 18 & 20 & 19 & 11 & 10
\end{tabular}


This table indicates that the average time spent on homework assignments is about seven hours per week. This appears to be a low average if one remembers that these students are carrying at least three academic subjects. This is just another factor indicating the conflict going on between the student's work program and his school studies.

In analyzing the answers to the question on the questionnaire, "Does your work interfere with your schooling?", it was interesting to note that of the 216 reporting, only 28 or about ten per cent stated that there was any interference. Yet all the previous tables have indicated that many conflicts do exist, apparently without the knowledge of the students. Perhaps too many of these students are more concerned with the mere money making than anything else. This is shown by reference to Table XVI, in which less than half of the students feel that their jobs will lead to any worthwhile activities in the future. In other words, these students are taking any jobs that they are offered, without too much thought of the consequences to their future or to their present schooling.

The conflicts are concerned with the questions which involve the area of extra-curricular activities, outside school assignments, and earning enough for maintenance. Possibly these conflicts may be ameliorated if the students are placed more carefully in situations better suited to their needs, and if an effort is made to coordinate work programs with the school's academic plan. 
Job Classification

The division of the work of the students into appropriate categories may be accomplished by various methods. For the purpose of this study it was decided to divide the types of student employment into four categories, since it was found that 95 per cent of the jobs could be included in such a division. The main groups selected were: sales, service, clerical, and industrial work. An attempt was made to group types of jobs together as far as possible.

Of the total 228 jobs reported, 33 per cent worked in sales; 25 per cont were employed in various types of services; 26 per cent were employed in olerical work, while only 11 per cent reported industrial work. Five per cent fell in the categories of miscellaneous work, including such oocupations as library work and agriculture.

TABLE XII

A CLASSIFICATIO IV SEX OF THE TYYES OF WORK DONE BY STUDENTS OF THE LOUISVILLE SEINIOR HIGH SCHOOLS EMPLOYED PART TIME, AS INDICATED BY A SURVEY CONDUCTED APRIL, 1947.

Type of Work

Sales

Service

Clerical

Industrial

Miscollanoous
Total Reporting

77

56

68

27

16
Boys Girls

$21 \quad 56$

$38 \quad 18$

$27 \quad 41$

$8 \quad 19$

$8 \quad 8$ 
A CLASSIFICAIION OF PYPES OF WORK DONE BY STUDFINS EMPLUYED FART TIME IN LOUISVILLE SENIOR HIGH SCHOOLS, AS INDICATED BY A SURVEY, AFRIL, 1947.

\section{SALES WORK}

\begin{tabular}{|c|c|c|c|c|c|c|c|c|c|}
\hline$\frac{\text { Type of }}{\text { Work }}$ & Boys & $\frac{\text { Eivs }}{\text { ijris }}$ & AIHERTON & $\frac{\text { CENIRAI }}{\text { Boys Girls }}$ & HALLECK & MALE & MAIVUAL & SHAWNEE & TOTAL \\
\hline Dept. Store & & 2 & 7 & & 3 & 2 & & 13 & 27 \\
\hline "Soda Jerk" & 1 & & 1 & 1 & 2 & 1 & & 1 & 7 \\
\hline Grocery & 3 & 1 & & 1 & & & 1 & 2 & 8 \\
\hline Drugs & & & 1 & 1 & 3 & 2 & 3 & 2 & 12 \\
\hline $\begin{array}{l}\text { Specialty } \\
\text { Stores }\end{array}$ & 1 & 2 & 3 & $\therefore$ & 4 & 1 & 2 & 8 & 21 \\
\hline Total & 5 & 5 & 12 & 2. $\quad 1$ & 12 & 6 & 6 & 26 & 75 \\
\hline & & & SE & RVICE WORK & & & & & \\
\hline Baby Sitting & & & & 1 & 1 & & & & 2 \\
\hline Movies & 2 & & & 1 & 1 & 1 & 5 & & 10 \\
\hline INurses Aid & & & & & 2 & & & & 2 \\
\hline Bus Boy & & & & 3 & & 1 & & & 4 \\
\hline Waitress & & & & 1 & 1 & & & & 2 \\
\hline Gas Station & 2 & & & & & 2 & 1 & & 5 \\
\hline Janit or-Porte & & & & 4 & & & 2 & & 9 \\
\hline Newspaper & & & & 7 & & 5 & 9 & & 15 \\
\hline Total & 4 & & & 6 & 5 & 9 & 17 & & 49 \\
\hline & & & INDI & ISTR IAL WOE & & & & & \\
\hline Telephone & & 1 & 3 & & 3 & & 1 & 11 & 19 \\
\hline Metal \& Wood & 3 & & & & & & & & 3 \\
\hline Truck Driver & 1 & & & 1 & & 1 & & & 3 \\
\hline Mechanics & 1 & & & 1 & & & & & 2 \\
\hline TotaI & 5 & 1 & 3 & 2 & 3 & 1 & 1 & 11 & 27 \\
\hline
\end{tabular}


CLERICAL WORK $\frac{\text { Type of }}{\text { Work Done }}$ Boys Girls $\frac{\text { AHRENS }}{\text { Boys Girls }}$

\begin{tabular}{|c|c|c|c|c|c|c|c|c|c|}
\hline Typing & & 12 & 1 & & & 4 & 1 & & 3 \\
\hline Stock & & 3 & & 2 & 1 & 2 & 2 & 2 & \\
\hline Grocery & 2 & 3 & & 1 & & 1 & 2 & 6 & \\
\hline General & 3 & 2 & & & 1 & 4 & 2 & 3 & \\
\hline Cashier & & & 1 & & & 2 & & & 1 \\
\hline
\end{tabular}

MTSCELLANEOUS JOBS

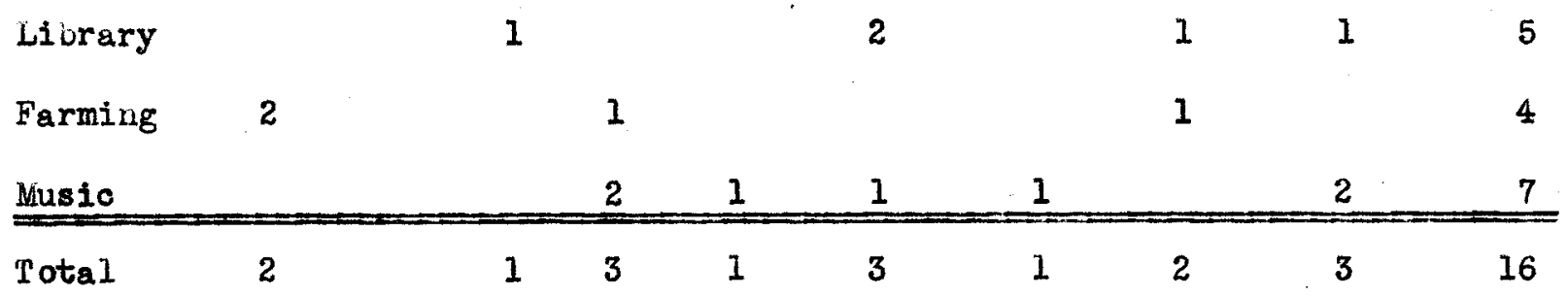

In making any analysis of jobs and their effects on the students it should be stated at the outset that certain unneasurable qualities are inherent in many of these jobs. For example, there may be some jobs, especially during prosperous times, that may y weil, but which ultimately have little value. Other jobs may be psychologically bad in specific insianoes if the students develop social maladjustments as the result of the work. Ihese points are mentioned as they are unmeasurable, and any recommendations can hardly take them into aocount. One such example might be the intensified racial antagonism resulting from association with a very bitterly prejudiced group of men. This prejudice may be found in jobs where voth ivegro and white boys would ve competing for the same manual laboring jov. Examples of this are found in packing, crating, hawling, and construction work. 
One of the most important aspects of the jobs from the training program viewpoint is whether a partioular task is going to benetit the student in the ruture. In connection with this point, the students were asked whether they felt their present jous had value for the future. ihe following table summarizes their responses.

\section{TABLE XIV}

A CLASSIFICATION OF STUDEIT'S INDICATING WHEIHER PRESHINI JOBS WERE LIKELY TO LEAD TO BETTER FUTURE EMPLOYMEIFI AS INDICATED BY A SAIRLE SURVEY CONDUCTED AMONG THE SRUDENTS WORKI WG PAR'T TIME IN THE LOUISVILLE, KENTUCKY SENIOR HIGH SCEOOLS, APRIL, 1947.

Replys $\frac{\text { AHREIS }}{\text { Boys Girls ALHERION }}$ CEYVIRAL HALLECK WALE MAWUAL SHAWNEE IOTAL

$\begin{array}{lrrrrrrrrrr}\text { Yes } & 9 & 17 & 7 & 5 & 4 & 12 & 9 & 18 & 22 & 103 \\ \text { No } & 10 & 6 & 11 & 9 & 5 & 21 & 13 & 23 & 27 & 125 \\ \text { Tot al } & 19 & 23 & 18 & 14 & 9 & 33 & 22 & 41 & 49 & 228\end{array}$

This seems to indicate that too many of the students are interested only in getting a job, rather than in learning some particular work which may be useful for later life.

\section{PABLE XV}

A CLASSIFICATION IN PERCENTAGE OF THE PERSONS WHO FELT THAT THEIR PARTICULAR TYPE OF WORK WOULD IEAD TO SOMETHING BETTER IN THE FUTURE, AS INDICATED BY A SAMPLE SURVEY OF THE STUDFNTS ERPLOYFD PART TIME IN THE SENIOR LIGH SCFOOLS OF LOUISVILIE, KENTUCKY, APRIL, 1947.

Type of Work

Sales

Service

Clerical

Industrial

\section{Percentage Reporting a Future to the Work}

\section{5}

45

60

75

This table shows that only 35 per cent who were engaged in sales work felt that their jobs would lead to a better job in the future, while 75 per cent of those engaged in induetrial work felt that their jobs would 
lead to more profitable employment. This indicates that the industrial jobs are more rewarding from the standpoint of making a career for the student than other work. Lowest on the scale is saleswork which in almost all cases reported was of a temporary nature. The majority of students who were doing sales work were employed possibly one or two afternoons in adition to $s_{a}$ turday. Sales work seems to be particularly popular among girls, since 75 per cent of those reporting sales work were girls.

The general opinion of most of the people who answered the questionnaires and who were participating in sales work indicates that sales work provides a moans of meeting adults, and partioipating with them in commercial transactions. This aspect of developing the personality of sheltered adolescents is indicated by a statement which on girl made:

My job enables me to meet people. Before I started working. I had only a few close friends, and had no contacts with adults outside of my own family.

The boys who were engaged in selling activities expressed fow comments other than the feeling of personal satisfaction which came from being able to sell an article and the feeling of independence which oame from the experience of meeting people.

In services, newspaper carrying was the highest ranking occupation among the boys. This work carries with it a good many responsiwilities such as acoounting, dependability of service, and organization of route. This work has been traditional for generations of school boys, and it appears that it still furnishes a meaus of pooket money for many young people.

Among the girls, nursing service was listed by some as having future value. First it may furnish a basis for continuing in a career 
after high school. But more important from a social viewpoint is the value to the community and their future families if these girls have received training in the techniques of nursing. If the schools are not fully equipped to teach this useful subject, then all of the outside training that can be secured is to the girls' credit. This is true since a large part of the work of the wife and mother is concerned with the bearing and raising of children, and looking after the general physical welfare of the entire family.

Baby sitting seems to be an occupation frequently found among teen age girls and college girls. The tralue often is questionable in that fow girls do more than read while the infant sleeps. Again this job could de made more useful if girls could seoure training in child psychology. Among the occupations finding favor among the services types were ushering and ticket selling in movies. No significant comments were mado on the schedules in respect to this work. However, in the opinion of many educators, there has been agreement that night work is not conducive to studying outside of school. Particularly would this be true of movie ushering. Here there is little opportunity for the boys to do constructive work. Possibiy some learn a few of the techniques of theater management, but for the most part this sort of training should be gained as a definite occupational training after high school graduation.

There was a high incidence of ivegroes in the janitoring services. This is to be expected due to the few economically secure positions open to liegroes in our society. In trying to make any estimate of these janitoring jobs, a few comments from the questionnaires may help: This is merely a means of earning spending money now. This job is not very good but I have to help at home. 
Apparently these janitoring jobs of fer little except manual

labor to the boys concerned. If we are going to try to achieve an integration of the Negroes in this community, a good high sohool work program could be very useful. If the oncoming ivegro youth are not trained for anything useful, the community as a whole will suffer in future years. It is vital that the Negro youth be included in any program for total youth organization.

The large percentage of individuals reporting that olerical work could lead to a more profitable future will now bo analyzed. In the general oategory of clerical work, typing and filing duties in commercial establishments seemed to predominate. The need for such work is very fundamental to girls and boys going into oommeroial vocational training. Both boys and girls expressed interest in filing and in over 60 per cent of the oases desired to oontinue after completion of their sohooling. These olerical positions offer an excellent opportunity for integrating in-school learning with practical work experience. Office positions of students in the Louisville schools are not however, held in conjunction with sohool work, but as an out-of-school method of making money. If a correlated school-work program were, established, the schools' course of study could be designed to help meet the needs of the work students' situation, making the total experience meaningful and valuable to both student and employer.

Grocery clerking by boys is too often merely a sorting and boxing of packages, involving no training program in store administration or maintenance. Again here is an opportunity for the part time student employees to loarn a very important business, but if these boys are engaged only in simple physical tasks, their potential skills will not be developed. 
Among the industrial workers, the largest percentage of the boys came from Ahrens. This is to be expeoted since Ahrens has a cooperative program designed for its seniors. The fact that, five out of nine of the industrial workers came from Airens toids to be indicative of the success of their vocational training program. This training program could be extended as well to other students, even though they did not plan immediate use of their vocational training.

It is not to be argued from this that all schools should place a larger number of boys in industry. It should be remembered that Ahrens, being primarily a trade school, would place greater emphasis on industrial positions. Instead, this trend at Ahrens should indicate that locally, more emphasis may be placed on a sohool-work program, since if it works so well at one school, it could be spplied at other schools in fields other than industry.

The value for the boys working in industry is very high in terms of future experience. There is no reason why there should not be established a greater degree of coordination between school and industry, so that more young people may participate in industrial occupations. Miany of the boys expressed keen interest in the practice of their manual arts. Here then is one field open to part time employment whioh combines the interest of the student and a good work-training program.

The girls who participated in this survey and who held industrial jobs were employed as telephone operators. There were no other industrial joos listed by the girls. Of the eleven reporting that they were operators, it was found that the majority indicated that a means of earning spending money was the reason that they were employed. In other words, the accent was on acquisition of money for conspicuous consumption. 
The educational value of learning routine jobs may be less rewarding than would be desirable.

In summarizing these data, the relative advantages and disadvantages of these jobs have been disoussed. The analysis has attempted to indicate especially good points, and has likewise made critical suggestions when needed. It is hoped that these observations on the nature 0 of the jobs, and the suggestions of the last chapter may serve as the basis for a reexamination of the employment of our high school youth.

\section{Other Aspocts of the Louisville Analysis}

In analyzing the survey given here in Louisville the following facts were learned a jout the economic status of the persons tested. TABSLE KVI

A CLASSIFICAIIION OF MEMBERS OF THE FALILIES PROVIDING SUPYORI AS INDICATED BY A SURVEY CONDUCTED AWOLG THE STUD FNIS WORKING PARI TIME IN THE LOUISVILLE, KENIIUCKY SENIOR HIGH SCHOOLS, AFRIL, 1947.

Parent Working

ivumber of Students Reporting This Case

Percentage

Father only 158 Mother Only 14 46 Both Parents 10 Neither 228 71 7 21 Tota I 100

This information may have serious implications for the needs of the adolescent's home life. If only the father is providing the chief means of support of the f'amily, which seems to be the tendency in the group sampled, then it may well be that the children of high school age will have to pay for their own entertainment and clothing. When a sampling as was made indicates that such a large percentage of the families have only one provider, it is difficult to advise the children ageinst part time employment after school hours. 
In seven per oent of the cases the mother only was working. 'lhe death of the father was usually the reason stated on the questionnaires. Such situations provide very socially atypical backgrounds for the children. This comes about largely through a lack of contact between children and mother, especially when the mother is doing shift work. In such cases special efforts might be made to provide the student with special working hours to coincide with his mother's working hours. In this way, it will be possible for them to be together more frequently.

There should be no need for over ten hours of work per week in the cases of those students who report both parents working. Since 21 per cent of the cases reported both employed, it is possible that these students are working only for spending money. The opportunity for high sohool part time employment should not be denied these people, but generaliy those who have both parents working, should not be given first preference for higher paying jobs.

In a well organized system, precedence would be given to a hardship case, where there is an opportunity for steady or higher paying employment. The current social difficulties with child delinquency is an issue in this part of the problem. Normally there would be a greater chance for delinquency among young people who had little or no parental guidance during the hours spent at home: Although there should be no attempt to prevent the children working in cases where both perents are employed, certainly agencies should try to coordinate the work of the children with the working hours of the parents.

After presenting the data secured in Louisville, a selection of studies made in other cities will now be discussed. As was stated earlier, comparisons with other surveys tend to point out more sharply and clearly the major issues in the Louisville school-work program. 


\section{Analysis from Other Cities}

From the information presented in the following pages, it is seen that the group of students who are working part time share similar problems concerning both scholastio achievement and employment. To think that these problems are totally different from other groups in our society, would be an error. It is better to say that these issues are merely modifications. The following seleotions from educational and sociological literature attempt to show some of the difficulties and conflicts arising among the students.

In considering the importance of work done by adolescents, many have been prone to underestimate its effect. However, a San Francisco survey conducted in 1944 gave the following result: (1)

of the 12548 young people interviewed, 82 per cent had or wanted jobs, only 18 per cent didn't want jobs, and of these, 70 per cent were under 17. Five hundred more girls than boys wanted jobs. Of the 5,468 young poople working, only 13 per cent were working for experience.

This survey conducted during the wartime emergenoy still is indicative of the activity of young people on the job market, but again shows the need for a better directed program, not an aimless "looking for a job."

In Phoonix, Arizona, a survey was conducted which attempted a correlation of high school achievement with part time employment. (2) This survey was carried out under the auspices of the school, so that a control group method could be employed. The survey was conducted among the freshmen, sophomores, and junior classes at the Phoenix Union Central High School. After the taidations were made, three factors were considered: (I) Carmody, Mae. "Value of High School Work Census". Oocupations: \{द厶 348-51. Niaroh, 1944

Rodgers, E. L. "Comparisons of High School Achievement of High School Pupils Who Had Fart Time Employment with Averages of Their Respective Group". Journal of Educational Research: 34: 112-8. October, 1940 
sex, length of hours employed, and the record of scholastic achievement. The groups were divided into boys and girls and also freshmen, sophomores, and juniors so as to note any differences in academic work.

It was found that both boys and girls evidenced a greater number of failures among the freshmen and sophomore control groups than in the junior control group. This was also true of the people employed part time. In the cases of the girls it was found that those working in the freshmen group had more failures then the control group, but that after the freshmen year, there was no differences in the girls of the working group and those of the control group.

IQ records showed less than 1.5 points differenos in the median for the control group and the workers' group. However, IQ was found to be invereely proportional to the hours worked, as it was found that those boys with the lowest IQ's were employed for the greatest number of hours.

The length of time worked seemed to indicate that long working hours were conducive to failures, especially among the boys. The differenoes between the boys and girls cannot. be simply explained in this survey, as no further evidence was presented as to the types of work, or any of the circumstances of adjustment to the jobs.

For convenience, the tables from the freshmen survey have been presented below so as to illustrate the methodology employed by $\mathrm{Mr}$. Podgers.

\section{TABLE XVII}

A COMPARISON OF IQ, GRADE POINIS EARINED, PERIOD ABSENCES, AND SUBJECT FAILURES OF FRESHAEN BOYS WORKING PART I'IME FOR FAY WITII ALL FRESHMEN BOYS, BASED ON A SURVEY MADE IN THE PHOENIX UNION CELTRAL HIGH SCHOOL, PHOENIX, ARIZONA, 1939.

\begin{tabular}{|c|c|c|c|c|c|}
\hline$\frac{\text { ivumber }}{\text { Boys }}$ & Time Amp loyed & $I Q$ & $\frac{\text { Grade }}{\text { Foint }}$ & $\frac{\text { Per Cent of }}{\text { Period Absenoe }}$ & $\frac{\text { Per Cent }}{\text { Failure }}$ \\
\hline Class & Total Enrollment & 106.2 & 14.2 & & \\
\hline $\begin{array}{l}270 \\
22\end{array}$ & $\begin{array}{l}\text { Al1 Emp Loyed Boys } \\
20-35 \text { Hours }\end{array}$ & $\begin{array}{l}105.5 \\
107.1\end{array}$ & $\begin{array}{l}14.2 \\
13.4\end{array}$ & $\begin{array}{l}5.3 \\
6.3\end{array}$ & $\begin{array}{r}8.2 \\
11.2\end{array}$ \\
\hline 17 & Over $35 "$ & 102.8 & 12.6 & 8.1 & 12.5 \\
\hline
\end{tabular}


The following study was made by Wary R. Fisher in Philadelphia. (1)

Table XVIII shows a comparis on Detween the Louisville and Philadelphia studies. The survey was conducted in 1944 during the war emergency to ascertain the census of the part-time employment opportunites. Miss Fisher divided her findings into the same groups as I did.

\section{PABLE XVIII}

A COLPARISON OF PHE HOURS SPENT IN FART IME ELPLOYIEHS IN PHILADELFHIA AND LOUISVILLE, AS INDICATED BY SAHPLE SURVEYS OF THE HIGH SCHOOL PART TIME WORKSRS OF PHESE TWO CIIIES, DBCEHBER, 1944 AND APKIL, 1947 RESPECTIVELY.

Hours spent in Gainful Jobs
PHILADELUHIA

Per Cent $\frac{\text { TOTAI }}{\text { BOYS }} \frac{\text { GIRIS }}{\text { (These figures areali in percentages) }}$

$1-9$

10-19

$20-29$

30 and over
1210

$44 \quad 30$

$34 \quad 44$
13

55

27
37

30

22
16

27

39

11

100

$\frac{19}{100} \frac{6}{100}$

This table is to be interpreted in this way: Of the total number of people working in Philadelphia High Schools, twelve per cent were working less then ten hours per week, while among the boys, only ten per cent were working less than ten hours a week. The other categories of varying lengths of employment should be read in the same manner. Whe higher figures for the Philadelphia surveys in the longer ranges of working time are reflective of the wartime conditions.

Again it is seen trat long working hours are not uncommon. The effects of this may be diflicult to measure immediately by a survey. However, in terms of long range planning, it is very probable that the future health and general welfare of these people may be impaired by long hour of employment during employed pe riods. This is especially true when one real(I) Fisher, Mary R.: "Part i ime Employment of High Sohool Students". Occupations: 23: 161-3. Dec. 1944. 
izes that many of these students are carrying a full school schedule in addition to their employmeat.

The next comparison to note in the literature is the division of jobs by types. The following table presents a summary of the results of a San Francisco survey of 1943. (1) The table divided the jobs of the part time workers into categories according to skill, type of service rendered, and nature of the product.

TABLE XIX

A CLASSIFICAIIOIN OF JOBS OF HIGH SCHOOL BOYS AND GIRLS EMPLOYED PARI TIME AS REPORIED IN AIN AINALYSIS OF SAN FRANCISCO HIGH SCHOOLS DECEMBER, 1943.

Jobs

Retail

Service

Manufacturing

Commercial

Government

Gas Station

Wholesale

Miscellaneous

ivewspaper

Telephone

Transport

Printery

Shipyard
Total 1 Number

2427

658

478

470

284

192

194

192

117

125

88

75

14
Percentage of AlI

$$
45.0
$$

12.0

8.9

8.8

5.3

3.6

3.6

3.3

2.2

2.2

1.6

1.4

0.1

The above table has been inoluded to give some idea of the types of work being done in cities larger than Louisville. It is of interest to note here that retail sales work still claims a high percentage, namely

(1) Carmody, May: op. Cit. 
forty-five per cent of those working. However, the wider fields of interest such as federal government work, and a larger group of manual arts were reported too. In this survey, it should be recalled that some of these jobs were temporary due to the jaiture of the critical war period.

The following study is herewith summarized since the authors investigated the same problem as proposed in this thesis. Lheir work was done in the ivolan Intermediate School of Detroit, Michigan.

This study has attempted to answer the question: What has been the eifect of part-time employment on the scholastic achievement of boys in secondary schools? Two hundred and Ifity part-time employed boys were matched with 250 non-employed boys acoording to intelligence, curricular grade, and physical age within six months. Teacher's marks were used as a measure of achievement. For each pupil, the honor point average for mathematios, English, social science, and physical science, and all other subjects were combined to oalculate the overall grade.

In general it was found that physical science, social science, and total honor unit averages of the employed group were higher than the nonemployed group. In English and mathematios, the non-employed group had a slight advantage.

None of the differences was statistically significant. The major finding that this investigation has revealed is that part-time work for these boys has had no apparent deterimental effect upon the student's academio achievement as measured by teacher's grades. lastic Achievement". Journal of Sooial Psychology: 13: 1941: 419-22. 
CHAPTER THREE

PHE COOPERATIVE WORK PROGRAM 


\section{CHAPIER THREE}

The foregoing chapters have dealt with the historical background, and the local and national analyses of the school-omployment problem. An attempt has been made to relate the important aspects of my survey with other surveys to give some measure of comparison.

In this last chapter a critique of the school-work program will be presented, which will endeavor to show the solutions f'ound to be practical. Then a brief summary proposing definite steps to be taken in Louisville, will follow.

Having presented a baokground of the local high school parttime employment situation, the next major step will be the presentation of a pragmatic plan to correct the evils of the present situation. Such a program, acoording to most of the literature on the subject, should be broad enough to cover not only the small peroentage of students who are going to pursue oareers in a trade, but should be so designed as to provide opportunities for everyone. That is, the basis of any really good work program would be the placing of all students who indicated a desire for work in a suitable job. There should be a clearing agency through which jobs would be obtained. Preferably such an agency would work in close cooperation with an employment agency and the local schools.

The following plan was recommended by one group as an initial start for organizing youth:

Suggested Plan of Action to Start High School Work Program: (1)

1. The War Nanpower Comission should determine the needs of the community with reference to total labor force, and then with reference to the number of part-time jobs available.

2. The high schools should appoint counselors to get data on the backgrounds and needs of the students interested in the work program.

3. A publicity committee of public minded aitizens

(1) woollner, R. C. "Part-Iime Exployment of Youth". School Review: 52: 584-6, December, 1944. * The Har hanpower Commission would be replaced by a civilian group. 
should back a drive to arouse awareness in the looal employers.

4. All employment should be coordinated through the local employment bureau.

5. A careful cheokup should be made to ascertain if employers will establish a training program on the job.

6. Referrals for jobs should thea be hand led through the schools.

7. All of the laoor market should be supplied from registrants at the bureau.

To give an example of the effectiveness of this program, L. H. Hoover's artiole on the working of the plan in Exoelsior, Minnesota, is (1)

cited. This program was initiated in cooperation with the war effort in 1942. A placement bureau was first established for the organization of the project. After the employers started making their applications for workers, the program developed well. Cooperation of the teaohers was stressed in helping the pupils to adjust to their new situations. In general, a harmonious program was established, in which even the teachers made inspection trips to some of the establishments.

Another aspect of the program of securing suitable jobs for high school students is knowing about the home situation. It is advisable to know, for example, whether the parents are working, how much the income is, and what sort of job the father has. In the small percentage of cases reporting in the local survey that neither parent was working, the reason usually given that the parents were dead. It would seem that special attention should be given this group in any prom gram, since an orphan may have peculiar problems of adjustment.

(1)

Hoover, I. H. "Jobs for Pupils". Clearing Houses 17; 169-73 November, 1942. 
To make a comparison with the local survey, I am listing below the results of a similar survey conducted by Mary Fisher in Philadelphia.

TABLE XX

THE MEMBERS OF THE HOUSEHOLD WHO ARE WORKING AS INDICATED BY A SURVEY CONDUCTED IN A PHILADELPHIA SEIIIOR HIGH SCHOOL, 1944 AMONG IHE SIUDEINIS WORKING PART T TME.

Father Employed Oniy

Mother Employed Only

$\frac{\text { Per Cent }}{69}$

Both Parents

7

Neither Farent

18

Total

100

The tendenoy for both parents to work is becoming a major consideration in other urban areas in America. Mary Fisher's report is cited elsewhere in the thesis as it provided some basis of comparison of the problems of the part-time working populations of other schools. Wartime conditions may account for differences in the Louisville and Philadelphia surveys.

Having presented the survey and its findings, as well as the social implications, it would be wise to consider from an overall viewpoint the advantages and disadvantages of the work program. In general two arguments are current in educational circles. First, a school-planned work program is held to be valid only for trade schools, but not for people who are planuing professional careers. Second, there are those who maintain that all students should have incorporated with their academic training a certain amount of first hand experience. Now that the problem in the educational field has been stated, the observations of educators will be given from both the positive and negative approach. A few programs have been chosen for which attempts (1) Fisher, Mary: Op. Cit. 
have been made to deal with the subject of part time employment. A fairly objeotive view is given by these comments, since they have been selected from a wide spread area.

Again referring to Philadelphia's school-work program, another analyst, Bruce Le seur, found several advaintages in the school-work program. Students learned skills in operating machines and acquired new methods of clerical detail not possible in the school training program. İoo, a greater knowledge of geographical and cultural areas was acquired through the processes of many of the training programs. Accuracy in the work was stressed to the students during their out-of-sohool hours. Le seur felt that the students working and functioning in the adult world built a sense of belonging, which surpassed all of the other features combined.

In adition to these benefits, school work was improved, Le Seur reported. School credit was given for supervised work in industry or commerce, so that a part of the total curriculum became concerned with the work program. Employers and teachers interchanged ideas and visits, so that a greater feeling of community cooperation was developed. Students gave lectures in their English classes based on their experiences in commerce or industry. 
Le seur concluded his study with the following table which shows the types of jobs and the percentage in each category.

\section{(1)}

\section{TABLE XXI}

A CLASSIFICATION OF TYPES OF WORK DONE BY 254 STUDBNTS WORKING PAR' PIME IN THE PHILADELPHIA FIGH SCHOOLS, 1945.

\section{Type of Work}

Clerieal and Kindrod

Labor

Stock and Shipping

Sales Persons

Wrappers

Ourside Delivery

Services

Craits

Telegraph Wessenger

Learners in Professions

Caddies

News boys

\section{Per Cent}

21

18

15

15

9

8

5

2

1

1

0

\section{(*) Less than 1 per cent.}

In another survey in San Francisco, John L. Roberts gives some challenging facts and an even more arresting story. In 1942, it was announced that boys and girls might go to school for four hours and work for four hours. Credit was to be given for the time spent in working under supervision. The following quotations from Robert's study give a good appraisal of the program.

Placement on the job is made by the school

placement interviewer under cooperative arrangement with the U.S. Employment service. Every attempt is made to see that both the school program and the jok fit into the life plans of the pupil.

Robert's reported the following information about the pupils

after a year's employment:

Eighty seven per cent of the 615 students participating replied to the questionnaires. Jobs varied from life guarding to filing clerk, with the groater majority in

\footnotetext{
(1) Le Seur, Bruce L. "Philadelphia's School-Work Program". Ocoupations: 23 : 343-350, March, 1945.

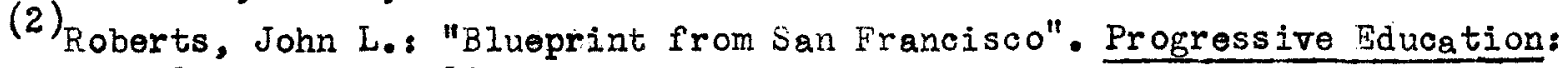
24: 66-71: November, 1946.
} 
distribuitive occupations. Only 7 per cent of the group felt that their health was not so good as when they entered the program. Sixty Ihree per cent said grades remained the same, and 29 per cent replied they had improved. (1)

Continuing his report, Roberts next listed the outcome of the questionnaires sent to employers. The following quotation is the importaut part of the data he collected:

The employer questionnaire asked the opinions of this group as to the value of the work experience to themselves and to the pupils, whether or not they planned to continue hiring part-time students, and whetiner or not they would hire the same students.

Seventy i'wo per cent of the employers returned the questionnaires. Of this number, 95 per cent felt the experience was worthwhile ior the students and 97 per cent felt the employers had benefited. Ninety Three per cont of tine employers intended to continue hiring students on a work experience basis, and 70 per cent would be willing to hire the same student. They felt the program should be expanded and be made more flexible and that pupils be more carefuliy selected for particular jobs. (2)

Roberts in oorcluding his report said that a survey of the scholastic grades of this group indicated that only 10 per cent dropped in scholarship, while nearly 40 per cent actually improved their record. I'his study could have tar reaching consequences if reports of this sort could be made in a larger number of oities. In this way, more generalizations could be made about employer-student relationsips. It would be dangerous to make any assumptions on the basis of this single survey. The nature of the war-time conditions and the emphasis on rocational training in the plan make it somewhat one-sided for many schools.

(1) Ibid.

(2)

Roverts, J. M. Ioid. 
It seems that somewhere between the extreme of rocational planning and no coordination at all, there should be a middle course that could be adapted to all high school students.

According to many of the leading educators, a well designed work program includes such elements as student participation in the adult world, and a greater emphasis on personal habits of dressing, heaith, and puncuality. Of course, if no eftort is made in selecting a good job, and the student is completely disinterested in his work, tien little of any value will be iorthcoming.

Some years ago, the Wational. Youth Administration was the leading Federal Agency which coordinated student employment. Mr. Mann, a director of the N.Y.A., summarized the social implications of a work progran.

The idea of work as a part of education

is in no way new. As a matter of fact,

it is as old as history itself. In the

earliest literature we can find, work is

not only a part of education, but a

principal means of education. We read

in the Talmud: "As the law is important,

so is the knowledge of work." (I)

After giving an excellent history of the working conditions in

the colonies and the reform laws of chila labor in England, Mr. Nann

continues:

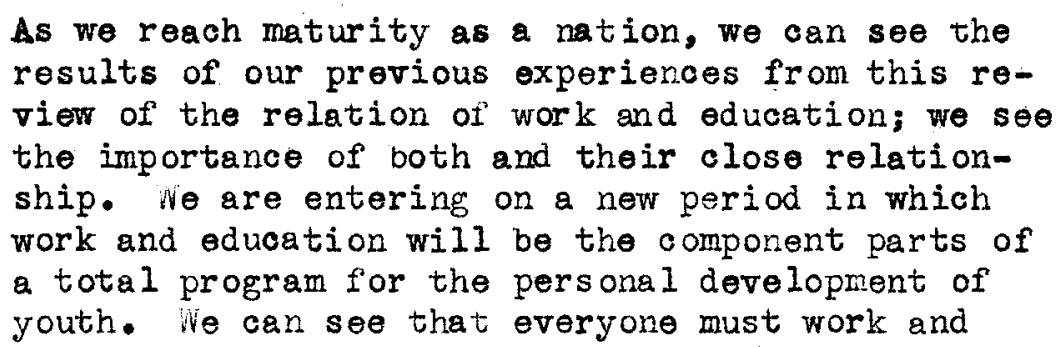

(1)

Wann, George C.: "Value of Work in Education in the Secondary School" Bulletin of National Association of Secondary School Frincipals: 25 :

77-83, Narch, 194I. 
contribute his share to the national income and receive his just share for his labor. we can see that the lot of man is work, and to stigmatize it and shun it, brings ruin to the individual and to the nation. We can see that all work and no leasure, as was the condition during the lowest period of our industrial setup, and that all education and no work, in its true sense, as was the case in more recent times, are both destructive. We must have philosophy with our daily living and reality with our education. ilore education in the early days would have prevented the vast destruction of our national resources, but education without an established contact with reality, means failure to utilize the vast human resources we have. we have to realize the importance of work and work experience as a vital phase of education. we must realize that both are important f'or the individual and to our democracy which is composed of individuals. (1)

In accordance with this philosophy of active participation, the f'ederal government's NYA project was the most energetic expression yet manifested in this country. The program of fered a wealth of stimulating suggestions and aids in establishing workable programs for youth. Jobs were classified in five categories: (1) construction and maintenance; (2) departmental assistance projects, such as, library service, book repairing in school etc; (3) clerical and service assistants; (4) such semi-professional projects as first aid rooms, clinios, and playgrounds; and (5) those students who could work only on the school premises, or failed to fit into one of the other groups. This last group aided in the operation of visual aid sohool equipment, helping younger chilaren in lower grades, or being assistants to teachers.

This brief survey of the MYA has been included to indicate its usefulness in the past, and to add additional information in favor of the estaplishment of such a project.

(1)

Man, George C.: Ibid. 
So far only the favorable impressions have been given. Next the other facts should be presented. Rather than say that these reasons explain why school-work programs have failed, it would be safer to say that these are pitfalls to be avoided in formulating the program.

As has been pointed out in the local survey, the jobs requiring long hours are undesirable. In a system of work where the school takes no active part, the boys and girls have no guidance or ability to resist the demands of the employers offering jobs. Too often the students, although wanting to work only ten or twelve hours a week, are forced to work longer. The employers tell them that only persons willing to work 28 hours per week will be considered. Thus the student is automatically required to work these long hours.

In the local survey, several instances of this were reported. A f'ew comments will illustrate the situation.
At irirst I worked for about eight hours a week on Saturday and then my boss said I had to work two full afternoons.
I wanted a job as an usher, but the only way I could get it, was by working three evenings and Saturday.

In addition the employers have taken advantage of student labor during especially busy seasons, while not providing any work for them normally. If a school-work program comittee, were established, such bad practices would not de as likely to occur.

Hanma orought up another aspect of the failure of some systems. He says that too often work is given to the student without any sort of training program to correlate it with learning. That is, if a boy is told to loao articles in boxes or if he is given a broom and mop for eight hours a day, nothing has been accomplished of a constructive nature. This is not (1) Hanna, J. M.: "Is It Cooperative Education"?: Clearing House: 20: 473-4, April, 1946. 
to say that routine work is completely inadvisable, as actually such jobs may do a great deal for boys and girls who have never been given responsibilities at home. The point is rather that suoh routine work mast be given in a total program which will incorporate more useful learning situations.

Hanna points out too that the difficulty so often is that long hours merely mean that there is less time for education, recreation, and extra-curricular activities. If the student is unadjusted to the job, then even more far-reaching difficulties will be encountered in the administration. His final suggestion to make a school-work program more efficient is the hiring of a full time co-ordinator in charge of the placement of aotivities, so that competent integrated work may de accomplished.

Those who feel that pragmatic experiences are worthless stress the necessity of a fully rounded academic background to meet the needs of the world community, rather then practical viork experience. Ihey emphasize the lack of proper educational background for these future citizens if they are forced at an early age to give up a portion of their school hours to working.

The answer to these prople would seem to be to make an analysis of the progressive systems that have had a correlated work program long enough to have produced prople who have actually started oil their careers. In this way, a comparison could be made to show what importance the successfully adjusted individuals gave to their earlier training.

An integral part of the school work program is the problem of persons dropping out of school because of economic hardships. Recognizing the need for more data on the subject, the ivational Child Labor Comitiee made an extensive investigation. The following sumary is an abstract of Mir. Harold J. Dillon's work with the Cormittee. 
According to Dillon's report, a rt-time program establishes:

(I) A tendency to hold in school students who might have otherwise left for full time work.

(2) An improvement in attendance and scholarship.

(3) A critical self-appraisal of students.

(4) A job-placing in line with the students abilities rather than in a totally unrelated position.

(5) A Detter safeguard against violation of ohild labor laws.

(6) A sense of belonging to the adult world.

(7) A greater confidence among the adults of their children's abilities.

(8) A basis for the teacher's evaluation of technical skill.

(9) A basis for job orientation through a job training program.

(10) A better basis for education-labor-management relations and the consequences of their working together, for the good of the community.

This report sumarizes the advice of some of the nation's lead-

ing educational research groups. The problem left to the individual community is the need for its schools and industries to harmonize and make of its youth a well integrated group.

This chapter so far has emphasized the educators' views of the school-work program; next the local situation should be stated with reference to jobs for part-time workers.

A representative of the local Kentucky Employment Bureau reported in an interview that no part-time jobs existed at the moment with but one exception, packing and boxing. These jobs, though few in number, (1) Dillon, Harold J. "Work Experienoe in Secondary Education; a Study of PartTime School and irork Yrograms" "1946: National Child Labor Committeo. 
are available for boys who are willing to work in warehouses of the various produce and commeroial enterprises. There was reported a demand for girl stenographers, but these openings required full time employees. In general there was no organized division of the Bureau which made a practice of working with students seeking part-time work.

A part of the lack of interest of employers was attributed by some individuals to the poor cooperation that so many of the young people exhibited during their employment as war workers. Ihis idea though, was not (1) borne out by the San Francisco project.

Another aspect of the local problem has been the work done by outof-school people in the school age group. In conjunction with this problem, a study was made in Louisville in April, 1947 by the Labor Department. The following paragraphs sumarize the findings published in a preliminary report by Miss Elizabeth $S$. Johnson.

The survey was made through interviews with 500 young people and 40 employers choser as a cross section. The young people were divided into three age groups: 14 and $15 ; 16$ and $17 ; 18$ and 19. They represent a cross section of out-ofschool youth in the community.

The preliminary report showed that 44 per cent of the boys and girls, 14 and 15, who have left school and are looking for jobs have been unable to find jobs. In the 16 and 17 age bracket, the percentages dropped to 35 and of those, 18 and 19 , only 19 per cent failed to find work.

The survey showed that about half those under 18 left sohool without completing more than the eighth grade. The reason most frequently given was some dissatisfaction in relation to school. Next reas on was economic pressure.

These preliminary data indicate the need for an overall schoolwork program. If there had been a program in force which would have pro-

(1) Cf: P. 48 .

(2) Johnson, Elizabeth S.: "Preliminary and Inoomplete Rennrt of Findings to Louisville Cooperating Committee on Study of Youth Emplovment." Unpublished Report of U. S. Department of Labor, Division of Labor Standards. April, 8, 1947. 
vided a more meaningful interpretation of the school curriculum, many of these young people could have secured some measure of adjustment to their situations. 
CHAPTER FOUR

CONCLUSION 


\section{CHAPTER IV}

\section{Conclusion}

The survey made in Louisville raised the major question: "finat are the important effects of part-time work on high school studeris, from a sociological viewpoint?" At this point, it is unnecessary to repeat the findings incorporated in chapter two of this thesis, but to reiterate the general conclusions.

In considering the various relationships as a totality, it is seen that the following factors loom large as a result of the student's work:

(1) In general too much time is being spent on outside work to do justice to formal schooling.

(2) There is an unorganized school-work program.

(3) The partioular jobs and the reasons for the student's working are both of ten far from an ideal situation.

(4) There is a serious and immediate need for a basic solution to the educational work needs of high school students.

If it can be assumed that these are the major problems to be met, then the following proposal might be offered as a beginning plan to satisfy the student's noeds:

(1) Establish a well informed committee to determine through interviewing and ehecking of ponality inventory tests just what the vital needs of these young people are. At this point, it could be determined approximately what percentage wany and need outside work, what kind and how much. Too, a group of competent psychologists and sooiologists could serve as a counseling group to advise young people in their educational needs. 
(2) Present this information to the school authorities, so that a more effioient planning of plant equipment and personnel could be most advantageousiy employed. If the school authorities knew approximately what percentage of students wanted pre-college training and industrial training a much better use of spece and equipment could be effected.

(3) Organize a committeo of employers and teachers to work out an elaborate cooperative system which would meet the needs of all students who want to work, regerdless of whether or not they are going to college.

(4) Appoint a full time counselor in each high school who would be responsible f'or coordinating the specific students' activities in and out of school after jobs have been established in the community by the group referred to in the precediag statement.

There still remains one important question unanswered: "Will. Louisville be aile to carry out or even approximate such a program?" The answer to this lies with the entire population. The plan has worked elsewhere; it is not impossiole. It is hoped that soon this community may share with other american cities the benefits of a well integrated schoolwork program. 


\section{Bibliography}

\section{Periodiogls}

1. Carmody, Mae: "Value of High School Work Census" Occupations:

March, 1944.

2. Fisher, $\mathrm{M}_{\mathrm{a} y}$ R.: "Part Time Employment of High School students"

Occupations: Deoember, 1944.

3. Giles, L. N., \& Nemzek, C. L.: "Effect of Part lime Employment on Scholastic Achievement". Journal of Social Psychology: 13:

1941.

4. Gordon, Phoebe: "Teen Age Money Problems"

Clearing House: March, 1937.

5. Hanna, J. M. "Is It Cooperative Education"?

Clearing House: 20: April, 1946.

6. Hoover, L. H. "Jobs for Pupils"

Clearing House: 17: November, 1942.

7. LeSeur, Bruce L. "Philadelphia School Work Program"

Ocoupations: 23: March, 1945.

8. Nann, George C. "Value of Work In Education in the Secondary School"

Bulletin of National Association of Secondary School

Principa1s: 25: Warch, 1941

9. Roberts, John L.: "Blueprint from San Francisco" Progressive Education:

24: November, 1946.

10. Rodgers, E. L. "Comparis on of High School Achievement of

Iigh School Pupils who had Part Time Employment

With averages of Their Respective Groups"

Journal of Educational Research: October, 1940

11. Woellner, R. C. "Part Time Employment of Youth"

School Review: 52: December, 1944.

\section{Panphlets}

1. Dillon, Harold J. Work Experience in Secondary Education; a Study of PartTime School and Work Programs". 1946: National Child Labor Committee.

Publications of the United States Department of Labor

1. "Education and Employment Opportunities of Youth" Division of Labor Standards, Child Labor and Youth Employment Branch, Washing, D.C.

2. Johnson, Elizabeth s.: "Preliminary and Incomplete Findings

to Louisville Cooperstive Cormittee on Study of Youth

Employment". Unpublished Report, April 8, 1947. 
Schedule of Question for Part Time Work in high Schools

\# Sex: English Unit: ASR: IQ:

Extra-Curricular activities: (give specific activity and approximate hours spent in this)

Hours spent in an average school week outside of sohool on your sohool assignments.

Does your mother work?

Does your father work?

(That is, gainful employment)

Total hours spent in an average week in gainful employment

(This total refers to work for which you were oompensated

with actual monetary remeneration, not household chores)

You may fill in a list of days below if it helps to recall your work.

HOURS WORKED

Sun. Mon. l'ues. Ved. Thurs. Fri. Sat. ToraL

Was this money nocossary to maintain you in school?

(You need not answer this if you prefer not to.)

Type of work done: (Briefly describe your work, eg,, baby sitting, movie ushering, clerk, etc.)

Do you feel tiat this work will lead you to a botter job in the future, or is it merely a means of income at the moment?

In what specifio ways has your rt time work interferred with your sohooling?

Any general comments on your situation may be made below: 